\title{
The Mystical Unity of Existence - A Look at the Philosophical INTERPRETATIONS OF THE MYSTICS'VIEW Regarding the Unity vs. The Plurality OF EXISTENCE
}

\author{
Shiraz Husain Agha \\ Faculty of Philosophy, Al-Mustafa International University, \\ Qom, I. R. Iran
}

The Unity of Existence is a concept that was first proposed by mystics. However, this concept has been interpreted in different ways by different groups of scholars. This is due to the fact that these mystics did not always speak in an explicit manner. One of the groups that attempted to interpret this concept was the philosophers. An examination of the works of philosophers leads to the conclusion that there are at least 15 different philosophical interpretations of the Unity of Existence. Some of these interpret this concept epistemologically, while others interpret it metaphysically. Some of them are legitimate interpretations of the sayings of the mystics, while others contradict some of the other sayings of the mystics and, therefore, cannot serve as adequate explanations of this mystical concept. Nonetheless, they can still serve as independent interpretations of the unity vs. multiplicity of the Universe. In this article, the 15 different philosophical interpretations of the mystical unity of existence will be presented and the legitimacy of some of them will be assessed. Another discussion that is of primary importance is the truth or falsehood of these interpretations. This is something that cannot be addressed in this article and, yet, deserves to be examined independently.

Keywords: Unity, multiplicity, mysticism, interpretation, philosophy 


\section{Introduction}

Theoretical Mysticism revolves around two fundamental premises. The first of these is the Unity of Existence and the second is the concept of the Perfect Man. Out of these, the first is of primary importance and the latter is only a corollary of the first. There are many important discussions surrounding the concept of the Unity of Existence. Nevertheless, before any of these discussions can attain any definite conclusion, the meaning of this idea must be fully clarified. What is more, it seems that this is one of the most, if not the most difficult of debates concerning this topic. The reason for this is that mystics - for whatever reason - spoke in ambiguous terms that can be interpreted in various ways. Due to this, there has always been a divergence of opinion regarding the meaning of their viewpoints. In this article, some of the ways in which the concept of the Unity of Existence has been interpreted will be presented and explained. It is important to note that we do not claim that these are the only ways in which this concept can be interpreted. Rather, these are the ways in which others have - up to now - interpreted this concept. Nevertheless, this concept can also be interpreted in many other ways. We, also, do not wish to present the proofs for the truth or falsehood of any of these interpretations. These - and other topics - demand a separate examination. An interesting point worthy of consideration is that none of the interpretations presented here have been put forward by the mystics themselves. Rather, most - if not all of them - are interpretations that philosophers - albeit with mystical tendencies - have made for this concept. This topic is imperative since there are many works - both translations and originals that deal with this subject in Western academia. However, I have not come across any that actually properly define what it means or even deal with why it is rationally justifiable. The second of these two subjects is something that we will put off to a later time. However, the first is what we wish to address in this article - with the reservation that it will only be explained here in brief.

\section{The Unity of the Concept of Existence and the Sheer Multiplicity of its Instances}

In this interpretation, existence is a single concept that can be predicated of multiple instances in the external world. So, in the external world, there are a multiple number of beings for which a single word is predicated. This word possesses the same meaning whenever it is predicated for something. This idea is something that some of the theologians do not agree with. Some theologians are of the opinion that the word existence possesses numerous meanings and that when it is predicated for some subject it means the same 
thing as the subject. ${ }^{1}$ Philosophers have presented many proofs to reject this idea and have shown that the concept of existence is one. ${ }^{2}$ However, the instances of this concept are multiple. Being multiple, they must be different from one another. Yet, the concept of existence cannot be something real. Otherwise, it would mean that each of these instances would be composed of at least two parts: what it has in common with other beings and what makes it different from them. Thus, we have to say that the concept of existence is something unreal and a construct of the mind. ${ }^{3}$ This is - in fact - the opinion of the Peripatetic philosophers regarding the unity and multiplicity of existence. It is well known that the mystics generally had an unfavorable opinion of these individuals. Nevertheless, some are of the opinion that when the mystics spoke of the Unity of Existence this is what they had in mind (Rafi'i Qazwini 1988: 53-54).

It is true that this is an idea that can be presented as a possible interpretation of the unity of existence. However, we feel that this is not something that can be presented as an interpretation of the sayings of the mystics regarding this concept - especially as it has been manifested in the sayings and writings of ibn Arabi and his students. The reason for this is that many of these individuals presented their view as an alternative to that of the Peripatetic philosophers.

1 They say that the reason why the theologians came to adhere to this subject was that they assumed that if we say that "existence" means the same thing when it is predicated for God and His creatures it would mean that God's existence and that of His creatures would be the same. This is while, according to the Qur'an, there is nothing like Him. As Mulla Hadi Sabziwari has mentioned, this fallacy stems from confusion between the meaning of existence and its external reality. In other words, it is the reality of God's existence that is not like the existence of anything else - not the meaning of "existence".

2 One of these is the idea that it would lead to all propositions being self-evident - as they would be nothing but instances of the affirmation of something for itself - which is self-evident.

3 The Peripatetic philosophers found themselves in a bind with regard to the unity and multiplicity of existence. First of all, they said that the multiplicity of beings is something self-evident. It cannot be denied. Since they are numerous, they must have distinctions that make them different from one another. At the same time, the single concept of existence is something that is predicated for all of them. If we say that both the concept of existence - that they have in common - and the distinctions - that make them different - are both real then it would either lead to their being composed of parts or two concepts sharing a common instance in the external world. This is while the Peripatetic philosophers said that existences are simple and it is impossible for one thing to be the simultaneous instance of two concepts - otherwise, it would mean one thing is more than one thing. They also could not say that the thing that they have in common falls outside of their existences - since everything outside of existence is unreal. Thus, they felt that they had no choice but to say that beings are completely different from one another and that the concept of existence is simply a mental construct of the mind. 
What is more, these individuals explicitly stated that existence is one and that existence is God. If this interpretation was really what these mystics intended, then it would imply that they were of the opinion that God is simply a concept of the mind! Thus, we cannot take this as a serious interpretation of the Unity of Existence. However, it is possible to accept it as the Peripatetic interpretation of the Unity of Existence.

\section{The Unity of the Perfect Being}

In this interpretation, unity is a property of the reality of existence, not its concept. This makes this interpretation different from the previous one. Existence belongs to one being and that is God. God's creatures do not exist. However, in this interpretation by "not existing" we mean that they are not perfect. In other words, everything other than God is composed of existence and non-existence. Everything other than God possesses its own existence and lacks the existence of other things. For example, Zayd is Zayd. He is not anything other than this. We can only affirm him for himself and must negate everything else from him. What is more, since what each thing lacks is more than what it possesses, non-existence is more deserving of being predicated of it than existence. This is based upon the literary principle of "predominance" (taghlib) that states that if one of two concepts is more predominant in a being than the other it is possible to predicate the former for the being in question and to negate the other one from it metaphorically - even though it may actually possess the other concept and quality. This interpretation can be derived from some of the poems of Mulla Ahmad Naraqi. There, he says the following:

Understand your nothingness so that you know what you are. What is nothingness? It is your deficiency. It is your incapacity, your ignorance, your dependency and your abasement. (Naraqi 2002: 39)

Although this interpretation does not share the same objection as the previous one, it still is objectionable. The reason for this is that some of the mystics - or at least some of the most reliable commentators of the works of the mystics - have explicitly warned us from interpreting the sayings of the mystics in a metaphorical manner.

\section{The Unity of the Word "Existence"}

Based upon this interpretation, the only being for whom the word "existence" truly deserves to be used is God. We cannot use this word for anyone 
other than God. Of course, this does not mean that other things do not really exist. In fact, they do exist. However, since they are only copulative existences when they are compared with the independent existence of God, they do not deserve to be labeled "existent". For example, if there is someone who knows one matter from one science, he does not truly deserve to be called "knowledgeable" in comparison to the one who is a master of all of the sciences.

The sage, Mulla Abdullah Zanuzi, was an adherent of the $3^{\text {rd }}$ interpretation. In his famous work, al Lama'at al Ilahiyyah, he states the following:

The possible beings are realities that are connected [to God] and copulative dimensions [of His Being]... Their relation to Him is the relation of weakness to intensity, imperfection to perfection, and poverty to self-sufficiency... Therefore, the relation of the possible realities and the copulative beings [that are God's creatures] to the Reality of Existence and the Pure Existence [of the Divine] is the relation of non-existence to existence. This means that if He exists, then it is as if they do not exist when they are compared to Him [not that they do not really exist]. (Zanuzi 1999: 219)

This interpretation is similar to the previous in two respects. First of all, it is the unity of external existence - not the concept of existence. In other words, it wants to state that the external reality of existence is one - not just its concept. Secondly, both of these two interpretations limit external existence to God in a figurative manner. In other words, neither of them actually seeks to negate external existence from God's creatures. However, the difference between the $2^{\text {nd }}$ and $3^{\text {rd }}$ interpretations is the manner in which this metaphor is justified.

However, due to the fact that this interpretation understands the Unity of Existence in a metaphorical manner, it is plagued with the same problem as the previous one.

\section{The Unity of Existence and the Multiplicity of Beings}

This is a view that has been attributed to Muhaqqiq Dawani. He is of the opinion that existence is real and principal in the Necessary Being. However, the possible realities that are His creatures are quiddities that attain reality and enter the external world when they come into a relation with their Creator. In and of itself, quiddity is something unreal. However, when God creates it, quiddity becomes real. Thus, there is a duality in reality. It is composed of existence and quiddities. The possible realities that are God's creatures actually lack existence - even after God creates them. This is what separates this interpretation from the three preceding ones. In the previous two interpretations, God's creatures actually have existence 
- albeit a deficient one. Nevertheless, [even in this interpretation] these creatures do deserve to be called 'beings' (mowjud). In other words, they really lack existence but are really beings. This seems contradictory at first glance. Nonetheless, Dawani explains this by saying that the word "mowjud" (being) is a derivative (mushtaqq). In Arabic, it is not necessary for the being for which one is affirming a derivative to actually possess the infinitive (masdar) from which that derivative is linguistically derived. Rather, it is enough for that thing to have some relation with it. Dawani gives the example of the word "mushammas" (a tanner). This derivative is taken from the word "shams" (Sun). However, it does not imply that the being for whom it is used actually possesses the Sun. Rather, it simply implies that this person has a relation with the Sun, i.e. he works out in the Sun. A point worthy of consideration is the fact that, even though Dawani was primarily a philosopher, he never tried to rationally establish the verity of this theory. Rather, he simply stated that any specialist in metaphysics would intuitively affirm the truth of this matter (Dawani 1984: 52-53).

Aside from the philosophical problems that this idea is plagued with, it is incapable of serving of a satisfactory interpretation of the view of the mystics. The reason for this is that the mystics were the first proponents of the principality of existence. In fact, they presented the very first rational proofs for the truth of this claim. If this is true, it would imply that quiddity is absolutely unreal. Thus, we cannot accept the idea that the mystics believed in a duality in reality and that God existence is real, while regarding His creatures, it is quiddity that is real. Otherwise, it would imply that the mystics did not believe that the proofs for the principality of existence they presented were actually rational demonstrations incapable of being exempted.

\section{The Unity of External Existence and the Multiplicity of Conceptual Existence}

In this interpretation, there is only one real being in the external world. Nothing other than God actually exists. However, a number of different concepts can be abstracted from this One Being. In other words, this one being is manifested in the mind as numerous and distinct concepts. In this interpretation, the numerous manifestations of the One Being are in the mind and are limited to concepts. In fact, this is what makes this interpretation different from some of the other ones that we will see later where the numerous manifestations of the one true being are not only in the mind, but in the external world as well.

This interpretation has been attributed to Mulla Sadra. In some passages of his work, Iqaz an Naimin, one can see signs of this interpretation. Of 
course, in some of his other works, other interpretations can also be derived. It should not be left unsaid that one of the principles behind the legitimacy of this interpretation is the idea that it is possible for the mind to derive a multiplicity of ideas and concepts from a single and simple being. Of course, since we are not actually concerned with the truth or falsehood of these interpretations, here we will forgo this matter for now.

In the aforementioned work, Mulla Sadra says:

So, unity belongs to existence and multiplicity belongs to knowledge. This is because sometimes a multiplicity of meanings and concepts can be abstracted from one being (Mulla Sadra 2006: 26).

\section{The Unity of Existence in the Divine Knowledge and the Multiplicity of External Existence}

This interpretation, in a sense, is opposite to the previous one. Here, in the external world, there is a multiplicity of beings. In other words, God and His creatures both actually exist. However, at the station of God's eternal pre-knowledge, they exist as one, simple being. In other words, this interpretation only accepts the unity of God's existence and that of His creatures at the level of God's existence - before He has actually granted existence to them. At the stage of the existence of the creatures, they exist as separate and distinct beings. However, before God has granted them existence. He must possess knowledge of these beings. Otherwise, it would entail that God creates them ignorantly and without knowledge. This is something that is unacceptable. At the same time, knowledge is a relation between the known and the one knowing it. Before God has actually created the possible beings that are His creatures, they do not exist. So, the question arises as to what His knowledge relates to, i.e. what He knows. This is the famous philosophical dilemma of God's pre-knowledge of His creatures. Mulla Sadra attempted to solve this dilemma by saying that God has an eternal presential knowledge of His own existence. ${ }^{1}$ However, since God is the agent of His creatures and the one that bestows existence on them, He necessarily possesses the perfection of their beings within His own being. Otherwise, He would not be able to grant them existence. He could not grant something that He did not have. Hence, He must possess the existence of these beings within His own. Thus, in His eternal knowledge of Himself, He also has a presential knowledge of His creatures. Mulla Sadra says:

1 Presential knowledge, or knowledge by presence, is the direct knowledge of the existence of something without the medium of concepts. 
S. H. Agha, The Mystical Unity of Existence -

The unity of beings is used to refer to two meanings... The second of those is the following: In the witnessing of knowledge and the intellectual realm, things [other than God] exist by means of the Real Existence that is one with the Essence of the Creator ${ }^{1}$. However, in external existence and external witnessing ${ }^{2}$ they are separate from Him and distinct from His Essence. (Mulla Sadra 1994: 456-458)

\section{The Unity of the Independent and Absolute Existence and the Multiplicity of Copulative Beings}

Based upon one division, existence can be divided into independent and copulative existence. Copulative existence is the existence for which dependency and need are essential. Independent existence is the one for which independence is essential. The latter is specific to God. All of God's creatures are copulative existences. Nevertheless, both actually exist. In other words, being copulative in nature does not contradict the factual nature of the existence of the creatures. This is in contrast to the $12^{\text {th }}$ interpretation. This is an interpretation that has been ascribed to the mystics by some contemporary scholars, one of which is Misbah Yazdi.

However, this leads to an objection. The mystics clearly state that the creatures of God only metaphorically exist. How can we interpret their view in this manner? Misbah Yazdi answers this objection by stating that the mystics have their own special terminology that is different from the terminology of philosophy. ${ }^{3}$ So, when they say "metaphorical existence" this is not to be taken in literal terms. Rather, this is a technical term that means the same thing as the term "copulative existence" in philosophy. He says:

The best way to combine the words of the true mystics and the true philosophers is to say that their difference is [in reality] a difference of terminology and to interpret "metaphorical existence" that is used in the

1 This is a reference to the fact that God does not possess a quiddity.

2 God has two types of presential knowledge of His creatures. One is at the level of His own existence - before He has created them. The second is at the level of His creatures - after He has created them. The first was a concept that Mulla Sadra discovered while the latter was popular before him. Sheikh Ishraq was of the opinion that the existence of the effect is present before the existence of its agent. This presence leads to or is tantamount to the presential knowledge of the agent with respect to its effect.

3 In fact, this is something that cannot be denied. In fact, it is something that they explicitly warn their readers about. In his famous premise to his commentary upon the Fusus al Hikam, Qaysari mentions this fact and also clarifies some of the meanings of the terms that are also used by philosophers - albeit with different meanings. 
works of the mystics to mean copulative existence... This is a methodology that Mulla Sadra used in numerous places. (Misbah Yazdi 2001: I/426)

\section{The Unity of God's Effulgence and the Multiplicity of its Manifestations}

Based upon this interpretation, no philosopher or mystic can acquire any knowledge of the Essence of God. Rather, it is impossible for one to pass any judgment about the Divine Essence. We cannot say that it is one or multiple. The reason for this is that the Essence of God is absolutely unconditional (la bi shart maqsami). ${ }^{1}$ Passing any judgment or affirming anything for it would be a contradiction in terms. So, what do the various judgments that we make regarding God refer to? The adherents of this view state that they all refer to the Effulgence of God or the "All-Pervading Effulgence of God" (al faydh al munbasit) - not God's essence. This is one being, but it permeates all things. This permeation makes all multiplicity a manifestation of this being - not something alongside it. This is an interpretation that can be derived from some of the works of the contemporary sage, Jawadi Amuli:

The knowledge of all beings does not go beyond the Divine Breath or All-Pervading Effulgence.... The Essence of the Divine is not limited. It is for this reason that it is not ensnared by any intellectual or mystical "hunter". It is for this reason that there is not a problem within [the science

1 It is possible to divide the way we look at any given concept into three categories: 1 . It is possible to positively condition it with something. For example, we may say that Zayd will come to our home with the condition that we roast a turkey for him. 2. It is also possible to take that concept into consideration with the negative condition that the aforementioned thing does not exist. For example, we may say that Zayd will come to our home with the condition that we do not roast a turkey for him. 3. It is also possible to take that concept into consideration without any condition at all. For example, we may say that Zayd will come to our home regardless of whether we roast a turkey for him or not. In the first case, Zayd's arrival is conditioned with something positive. In the second case, his arrival is conditioned with something negative. In the third case, it is not conditioned with anything. However, in the last case we can look at this absence of a condition in two manners: 1. It is possible for us to take this lack of conditioning as a condition. 2. It is also to negate this condition as well as the other two types of conditions. In other words, the lack of any condition may also be a condition and it may not. The mystics are of the opinion that God's existence is unconditional in the second of the two abovementioned manners. This is while the First Manifestation of God is unconditional in the first manner. The other manifestations of God are either conditioned by something negative or something positive or by both of these. 
of] Mysticism whose subject is the Unconditional Essence of the Divine. (Jawadi Amuli 2007: IX/532)

\section{The Unity of Mystical Witnessing}

This interpretation is different from the previous ones as it is one in which the Unity of Existence is interpreted epistemologically - not metaphysically. In this interpretation, the existence of the creatures of God is not negated. Things other than God actually exist. Nonetheless, the mystic attains a stage in his spiritual journey where he no longer is able to see them. In order to explain, when the spiritual wayfarer completes the $1^{\text {st }}$ of his fours spiritual journeys ${ }^{1}$ and is annihilated in the Divine Existence he sees nothing but God. In this stage of his journey, he sees nothing other than his Beloved.

Agha Ali Mudarris Zanuzi interprets the Unity of Existence in this manner:

When the mystic says that nothing exists besides Him, "no one resides in the house ${ }^{2}$ other than Him" or that "there is nothing inside my shirt other than Him"... then he is relating one of the states of his [spiritual] journey. He is not referring to the system of existence qua existence or beings qua beings [that exist] outside of the mirror of his heart. (Zanuzi 1999: 246)

Of course, we cannot deny the fact that the unity of mystical witnessing is something that the mystics have referred to in many places in their works. However, they did not limit themselves to this matter. Rather, they very often stated something even more than this. In fact, the unity of mystical witnessing is often mentioned as a stepping stone for the Unity of Existence. Thus, it seems erroneous to interpret it in this manner.

\section{The Unity of the Reality of Existence and the Multiplicity of its Manifestations}

In this interpretation, existence is one person and there is no multiplicity within it. Nonetheless, this one existence is the existence of God and the existence of His creatures. In other words, all of God's creatures exist

1 The mystics say that there are four basic spiritual journeys. These are the following: 1 . The journey from creation to the Truth by creation. 2 . The journey from the Truth to the Truth by the Truth. 3. The journey from the Truth to creation by the Truth. 4 . The journey from creation to creation by the Truth.

2 That is, in the Universe. 
by means of the existence of God. They are not created by God. If they had been created by God then there would be a duality in existence and their beings would be different from that of God. Rather, they exist by means of the existence of God. So, what is the difference between God and His creatures? They do not differ in their existence. This is because one existence is shared by both of them. They are different in that God is the apparent and His creatures are what He has appeared in. Or, the creatures are the manifestations of God. In this interpretation, the manifestation possesses the same existence as that which it manifests. If we wanted to give a physical example for this, we might say the following: Say that a picture of someone has been carved into a mountain. The existence of the mountain is the same as the existence of the picture of this person. They are not separate entities. However, they are different in that the mountain has appeared in the picture of this person. Some contemporary scholars interpret the Unity of Existence put forward by the mystics as well as that which Mulla Sadra adhered to in this manner (Nabawiyan 2016: I/306). Another example that can help clarify this idea is the unity of the soul and its faculties. In order to explain, in the opinion of the Peripatetic philosophers, the human soul is equal to the power of reason or the intellect. This is a faculty whose function it is to understand universals. At the same time, the soul has certain faculties that serve as its tools. These tools essentially understand particular things or perform certain particular actions. They then hand over the result of their actions to the rational soul which also indirectly partakes of this particular knowledge. Nevertheless, the faculties have a separate existence from that of the rational soul. However, Mulla Sadra was of the opinion that the rational soul is one with its faculties. In other words, these faculties are lower levels of the rational soul. The rational soul manifests itself at a lower level in these faculties - or, to put it in more precise terms, levels. Thus, the existence of the soul is the same as the existence of the faculties. At the same time, they are different in that one of them is the manifestation or lower level of the other. God and His creatures are much the same. In fact, Mulla Sadra interpreted the famous saying of the Prophet - i.e. "He who knows his soul knows His Lord" - in this manner. Another example often given is that of a light that is emitted from a source. In the beginning, this light is very intense. However, as it gradually is reflected off objects, it grows weak. So, this is one light that is manifested in different manners. Only one light exists, but the manner in which it is manifested is numerous (Amini Nejad 2015: 142).

This interpretation is very similar to the $6^{\text {th }}$ one. The only difference between them lies in the fact that in the $6^{\text {th }}$ interpretation, the existence of God does not possess numerous degrees and levels - varying in intensity. Rather, it is a simple reality. Numerous concepts can be abstracted from this simple 
being. However, in the $10^{\text {th }}$ interpretation, these concepts are abstracted from the varying degrees of this one being.

\section{The Real Unity of Existence and its Metaphorical Multiplicity}

In this interpretation, there is only one real being and that is God. In other words, God's creatures do not really exist. Essentially, they are the instances of 'non-existence. Thus, there is no real multiplicity in existence. However, existence can be predicated for God's creatures in a metaphorical manner. This way of interpreting the existence of God's creatures is similar to the $2^{\text {nd }}$ and $3^{\text {rd }}$ interpretations mentioned before. However, the reason for this metaphorical affirmation of existence in this case is different from the reason mentioned in those interpretations. The reason for this in this case is that these creatures are manifestations of that existence - without really partaking of existence - in the manner that the previous interpretation admitted. Due to this metaphorical existence, God's creatures are "real" in the broad sense of the term. This interpretation can be ascribed to a contemporary expert on Islamic mysticism, Sayyid Yadullah Yazdan Panah. He writes:

Existence cannot essentially and factually be predicated for anything other than the existence of the Truth... The attribute of existence is not capable of being predicated for this multiplicity of manifestations in any way except an accidental and metaphorical manner.... The mystics do not absolutely negate the multiplicity that is observable in the external world or say that it is nothing and simply a figment of the imagination. (Yazdan Panah 2009: 161)

\section{The Unity of the Independent Existence and the Multiplicity of Copulative Beings}

This interpretation, like a few of the others before it, rests upon the premise that the creatures of God are copulative beings. In other words, their entire essences are copulative in nature. However, the distinction of this interpretation is that in it, this leads to the idea that they do not actually exist. In fact, in this interpretation, both existence and non-existence can be negated from them. This is something that, at first glance, seems impossible and it seems to be the simultaneous negation of contradictory concepts. However, its proponents stress the idea that this is not so. In order to explain, concepts can be divided into two basic categories. The first are the concepts that are independent. The second are the concepts that are not independent. Inde- 
pendent concepts can further be divided into those that are nouns and those that are verbs. Non-independent concepts are those that require an independent concept in order to be understood. An example of the latter are prepositions that need to be placed within a sentence to be understood. Now, since the subject and predicate of propositions are always independent, non-independent or copulative concepts cannot be placed as the subject or predicates of propositions. Thus, it is meaningless to affirm or negate existence or non-existence from them. In other words, existence and non-existence can only be affirmed or negated from something when that concept is placed as the subject of a proposition. However, copulative concepts cannot be placed as the subject of any propositions. Therefore, existence and non-existence cannot be negated or affirmed for them. To put it in better terms, the law of contradiction is only applicable for independent subjects. Since copulative concepts are not independent, they lie outside the jurisdiction of the law of contradiction. To put it in different terms, the copulative concept cannot be made a category of an independent concept. This is because one of the basic laws of any division is that the thing being divided must be predicable for the categories into which it is divided. Thus, we cannot, properly speaking, divide existence into copulative and independent existence. Thus, the creatures of God, which are copulative in nature, do not possess existence. This interpretation has been attributed to some of Mulla Sadra's contemporary commentators. Abd al Rasul Ubudiyyat writes the following:

It is not possible for the mind to affirm anything for the effect qua effect... It is not possible to say that it exists... or that it does not exist; the reason for this is that the effect - in and of itself - is a copulative being and we [previously] stated that the copulative being cannot be made the subject for any predicate. (Ubudiyyat 2009: I/221-222)

\section{The Real Unity of Existence and its Real Multiplicity}

This interpretation is similar to the previous one in that it admits that the creatures of God are copulative beings and, from this point of view, existence and non-existence are not capable of being predicated or negated from them. However, it differs from it in a subtle manner. That is that, in this interpretation, the creatures of God have two real dimensions to them. When they are compared to God, they are His creatures and His effects. However, when they are compared to one another some of them are causes of some others. From this point of view, it is possible that they may possess independence and that existence may be predicable for them. What is more 
important, both of these two dimensions are real and possess actual reality. Based upon this interpretation, existence is both one and multiple, but from two points of view.

It is possible to ascribe this view to the late sage, Allamah Tabatabai. He was of the opinion that both of the aforementioned dimensions are real. They are not simply conceptual. Rather, concepts rely - in their independence and dependence - on the instances from which they are derived. In and of themselves, concepts are neither copulative nor independent. Thus, if it is possible for one to derive two concepts from the creature of God, this implies that it actually possesses two dimensions to it in the real world. He writes:

In its independence or dependence, a concept depends upon the existence from which it is derived and, in and of itself, it is only something obscure. (Tabatabai 1982: I/27; 2002: 41; 2007: 30)

Also, he writes the following in his Nihayah al Hikmah:

The existence of every effect - regardless of whether it is a substance or an accident that exist independently - is copulative in comparison to its cause - even though, in and of itself and when some of them are compared to others, it may be a substance or an accident that exists independently.... So, the limitations of [the existence of] substances and accidents are quiddities that are substances and accidents when they are compared with one another or when taken into consideration in and of themselves. And, they are copulative beings when they are compared to their Primary Source, the Gracious and the Most High. (2007: 30-31)

Based upon this interpretation, Allamah Tabatabai would have to admit to the simultaneous unity and multiplicity of existence - albeit from two points of view. These two distinct points of view protect it from negating the principle of contradiction. The reason for this is that two propositions only contradict one another if they share 10 things in common. One of those is the unity of the points of view (haythiyyat) from which the subjects and predicates are understood.

\section{The Real Unity of Existence and its Imaginary Multiplicity}

This interpretation is different from all of the previous ones in that it absolutely negates existence from God's creatures. In each of the previous interpretations, some sort of existence could be affirmed for them - even if 
that was a metaphorical existence. However, in this interpretation, all types of existence are negated from them. The creatures of God do not exist independently from Him, with His very existence, with a copulative existence or even with a metaphorical existence. We cannot even say that they are really manifestations of the existence of God. Otherwise, it would allow us to metaphorically affirm existence for them. Thus, the creatures are simply figments of the imagination and constructs of the mind. Thus, based upon this interpretation, unity really exists, but multiplicity does not.

Mulla Sadra says the following regarding this interpretation:

Since most of those who have investigated the sayings of the divine saints have not understood their intentions and have not comprehended the essence of what they mean, they have assumed that... the possible beings are sheer constructs of the mind and that their realities are imaginations and fabrications [of the psyche] that do not have any existence other than that which is acquired through mental convention. (Mulla Sadra 2007: II/260)

Also, Mulla Abdullah Zanuzi says the following:

And this multiplicity is [in] our imagination and no multiplicity exists. (Zanuzi 1999: III/503)

\section{The Unity of the Totality of the Universe (i.e. Pantheism)}

In this interpretation, God is nothing but the sum total of the universe. The beings of the universe are His parts. God possesses the unity of a whole in this view. Mulla Sadra ascribes this view to the 'ignorant Sufis'. In his book, Iqaz an Naimin, he writes:

Some of the ignorant Sufis surmise that... Allah is the manifest collection [of the creatures]... (Mulla Sadra 1994: 38)

\section{Conclusion}

In conclusion, we can say that the Unity of Existence is a mystical concept that is open to interpretation. It has been interpreted by many types of scholars in many different manners. One of the groups that have attempted to interpret this idea is the philosophers. There are at least 15 philosophical interpretations of this idea. Some of these can legitimately be ascribed to 
the mystics, while others cannot. However, these are not the only possible ways in which this concept can be interpreted. Rather, the mind can think of many other ways to possibly explain this concept.

Received: January $13^{\text {th }}, 2017$

Accepted: April $10^{\text {th }}, 2017$

\section{Bibliography}

Amini Nejad, Ali (2015), Hikmat Irfani, Qom, Moassisah Imam Khomeini.

Dawani, Muhammad ibn Asad (1984), al Rasail al Mukhtarah, Isfahan, Kitab Khanah Umumi Amir al Muminin.

Jawadi Amuli, Abdullah (2007), Rahiq Makhtum, Qom, Isra.

Misbah Yazdi, Muhammad Taqi (2001), Sharh Asfar, Qom, Moassisah Imam Khomeini.

Nabawiyan, Sayyid Muhammad Mahdi (2016), Jastarhayi dar Falsafah Islami, Qom, Majmah Aali Hikmat.

Naraqi, Ahmad (2002), Khaneye Del, Qom, Anjuman Athar wa mafakhir e Qom.

Rafi'i Qazwini, Abul Hasan (1988), Majmu e Rasail wa Maqalat Falsafi, Tehran, al Zahra.

Sadr ad Din Shirazi (Mulla Sadra) (1994), Asfar, Tehran, Wizarat Farhang wa Irshad Islami.

Sadr ad Din Shirazi (Mulla Sadra) (2006), Majmua Rasail Falsafi, Tehran, Hekmat.

Sadr ad Din Shirazi (Mulla Sadra) (2007), Iqaz an Naimin, Tehran, Bunyad Hikmat Sadrai.

Tabatabai, Muhammad Husain (1982), Hashiyah al Kifayah, Qom, Bunyad Ilmi wa Fikri Allamah Tabatabai.

Tabatabai, Muhammad Husain (2002), Bidayah al Hikmat, Qom, Nashr Islami,

Tabatabai, Muhammad Husain (2007), Nihayah al Hikmah, Qom, Moassisa Imam Khomeini.

Ubudiyyat, Abd al Rasul (2009), Dar Amadi bar Nizam Hikmat Sadrai, Moasissah Imam Khomeini.

Yazdan Panah, Yadullah (2009), Mabani wa Usul Irfan Nazari, Qom, Moassisah Imam Khomeni.

Zanuzi, Ali ibn Abdullah (1999), Majumu e Musannifat Hakim Muassis Agha Ali Mudarris tehrani, Tehran, Nashr Ittilaat. 